\title{
Profil kadar hemoglobin pada anak yang tinggal di sekitar tambang emas Kecamatan Talawaan
}

\author{
${ }^{1}$ Thirza R. Kapal \\ ${ }^{2}$ Sarah M. Warouw \\ ${ }^{2}$ Hj. Nurhayati Masloman
}

\author{
${ }^{1}$ Kandidat Skripsi Fakultas Kedokteran Universitas Sam Ratulangi Manado \\ ${ }^{2}$ Bagian Ilmu Kesehatan Anak Fakultas Kedokteran Universitas Sam Ratulangi Manado \\ Email: thirzakapal12151@gmail.com
}

\begin{abstract}
Human interaction with the environment is a natural process since human birth until death. However, there are some disadvantages during the interaction process, inter alia exposure to inorganic metals, such as mercury, lead, cadmium, and arsenic. Even in a relatively very low concentration, they are still harmful to our helath. This study aimed to determine the level of hemoglobin in children living near a gold mine in Talawaan District. This was a descriptive observational study with a cross-sectional design. Of the total sample of 72 respondents, there were 31 males (43\%) and 41 females (57\%). There were 4 females (5.5\%) who suffered from anemia. There were 3 respondents of 13 years old that suffered from anemia, but there was only 1 respondent of 14 years old that had anemic. Conclusion: In this study, hemoglobin level of most children was relatively normal. Anemia was found only in a small percentage of female respondents.
\end{abstract}

Keywords: hemoglobin, heavy metal, children

\begin{abstract}
Abstrak: Interaksi manusia dengan lingkungan hidupnya merupakan suatu proses yang wajar dan telah terlaksana sejak manusia itu dilahirkan sampai ia meninggal dunia. Dalam proses interaksi manusia dengan lingkungannya ini tidak selalu mendapatkan keuntungan. Terdapat faktor-faktor tertentu yang dapat merugikan manusia. Pencemaran lingkungan bersumber dari kegiatan manusia salah satunya akibat penambangan emas. Bahan an-organik seperti beberapa jenis logam yaitu merkuri, timbal, kadmium, dan arsen, dengan konsentrasi yang relatif kecil sudah dapat membahayakan makhluk hidup. Penelitian ini bertujuan untuk mengetahui kadar hemoglobin pada anak yang tinggal di sekitar tambang emas Kecamatan Talawaan. Jenis penelitian ini ialah deskriptif observasional dengan desain potong lintang. Dari jumlah sampel sebanyak 72 responden, didapatkan 31 responden (43\%) berjenis kelamin laki-laki dan 41 responden (57\%) berjenis kelamin perempuan. Terdapat 4 responden $(5,5 \%)$ mengalami anemia yang berjenis kelamin perempuan. Pada usia 13 tahun didapatkan 3 responden mengalami anemia dan pada usia 14 tahun 1 responden mengalami anemia. Simpulan: Kadar hemoglobin pada anak yang tinggal di sekitar tambang emas Kecamatan Talawaan relatif normal; hanya sebagian kecil yang berjenis kelamin perempuan mengalami anemia.
\end{abstract}

Kata kunci: hemoglobin, logam berat, anak

Interaksi manusia dengan lingkungan hidupnya merupakan suatu proses yang alamiah dan telah terlaksana sejak manusia itu dilahirkan sampai ia meninggal dunia. Hal ini disebabkan karena manusia memerlukan daya dukung unsureunsur lingkungan untuk kelangsungan hidupnya. Udara, air, makanan, sandang, pangan, dan seluruh kebutuhan manusia harus diambil dari lingkungan hidupnya. Dalam proses interaksi manusia dengan lingkungannya tidak selalu mendapatkan keuntungan. Terdapat factor-faktor tertentu yang dapat merugikan manusia. ${ }^{1}$

Interaksi manusia dalam mengelola dan 
mengolah lingkungan sangat berperan terhadap kesinambungan pembangunan namun dalam UU no.18 tahun 1999 (a) tercantum bahwa dengan meningkatnya pembangunan di segala bidang, khususnya pembangunan di bidang industri maka semakin meningkat pula jumlah limbah yang di hasilkan termasuk yang dapat membahayakan kesehatan dan terjadi pencemaran lingkungan hidup manusia. Seiring dengan kemajuan teknologi dan globalisasi, pembangunan merupakan hal yang tidak dapat dihindari oleh setiap negara. Dalam UU no.18 tahun 1999 (b) menyatakan bahwa lingkungan hidup perlu dijaga kelestariannya sehingga tetap mampu menunjang pelaksanaan pembangunan yang berkelanjutan. ${ }^{2}$

Dalam UU no.32 tahun 2009, tentang Perlindungan dan Pengolaan lingkungan hidup, pencemaran lingkungan didefinisikan sebagai: Pencemaran lingkungan hidup adalah masuk atau dimasukkannya makhluk hidup, zat, energi, dan/atau komponen lain ke dalam lingkungan hidup oleh kegiatan manusia sehingga melampaui baku mutu lingkungan hidup yang telah ditetapkan. Pencemaran lingkungan berasal dari berbagai sumber, baik yang berasal dari proses alam maupun kegiatan manusia (antropogenik), pencemaran yang disebabkan oleh proses alam misalnya banjir, tanah longsor dan lain-lain, sedangkan pencemaran bersumber dari kegiatan manusia salah satunya akibat penambangan emas. ${ }^{3}$

Pencemaran yang berasal dari kegiatan manusia ini bisa berlangsung terus-menerus. Misalnya bahan an-organik seperti beberapa jenis logam yaitu merkuri, timbal, kadmium, dan arsen, dengan konsentrasi yang relatif kecil sudah dapat membahayakan makhluk hidup. ${ }^{4}$ Bila tersingkap di permukaan bumi akibat proses geologi atau aktivitas pertambangan, komposisi unsur tersebut dapat bereaksi dengan udara, air serta terlarut akan mengalami perubahan komposisi kimianya. Hasil proses tersebut dapat menghasilkan unsur -unsur kimia beracun/berbahaya yang masuk ke dalam sistem air atau yang terurai di dalam tanah, kemudian terserap tanaman, hewan dan ke manusia. ${ }^{5}$

Di Indonesia juga telah terjadi pencemaran logam berat yang sudah tergolong tinggi terjadi di perairan Teluk Jakarta yang ditemukan oleh Yatim et al. Hasil penelitiannya menunjukkan bahwa air laut, udang, dan kerang-kerangan telah tercemar oleh merkuri $(\mathrm{Hg})$, timbal $(\mathrm{Pb})$, dan kadmium (Cd). ${ }^{6}$ Menurut Depkes RI tahun
1989 kandungan logam berat timbal $(\mathrm{Pb})$ di perairan Ancol juga telah melampaui batas maksimum dalam ikan sokang sehingga ikan ini tidak aman untuk dikonsumsi oleh manusia. $^{7}$

Dari catatan Bank Dunia, URBAIR 1994, terlihat bahwa dampak pencemaran udara oleh timbal $(\mathrm{Pb})$ di Indonesia telah menimbulkan berbagai masalah kesehatan bagi manusia, angka kematian menjadi 340 orang per tahunnya. ${ }^{8}$ Masuknya logam berat melalui saluran pernapasan (insang) pada ikan nila dapat menyebabkan anemia pada ikan tersebut. Semakin tinggi tingkat konsentrasi logam berat, maka semakin rendah tingkat kelangsungan hidup dan pertumbuhan. ${ }^{9}$

Penelitian ini bertujuan untuk mendapatkan profil kadar hemoglobin pada anak yang tinggal di sekitar tambang emas Kecamatan Talawaan saat ini.

\section{METODE PENELITIAN}

Jenis penelitian ini ialah deskriptif observasional dengan desain potong lintang. Subjek penelitian ialah anak berusia 13-15 tahun yang duduk di SMP kelas 1-3 di sekitar lokasi pertambangan (Kecamatan Talawaan, Kabupaten Minahasa Utara), mulai bulan November 2015 sampai dengan akhir bulan Januari 2016. Variabel yang digunakan ialah anak-anak yang tinggal disekitar lokasi pertambangan Talawaan dan kadar Hb.

\section{HASIL PENELITIAN}

Berdasarkan Tabel 1 dari jumlah sampel penelitian sebanyak 72 responden, di dapatkan 31 responden (43\%) berjenis kelamin laki-laki dan 41 responden (57\%) berjenis kelamin perempuan.

Tabel 1. Karakteristik sampel penelitian berdasarkan jenis kelamin

\begin{tabular}{ccc}
\hline Jenis kelamin & n & $\begin{array}{c}\text { Persentase } \\
\mathbf{( \% )}\end{array}$ \\
\hline Laki - Laki & 31 & 43 \\
Perempuan & 41 & $\mathbf{5 7}$ \\
Total & 72 & 100 \\
\hline
\end{tabular}

Berdasarkan Tabel 2 dari jumlah sampel penelitian sebanyak 72 responden, didapatkan usia 13 tahun sebanyak 44 responden $(61,2 \%)$, usia 14 tahun sebanyak 19 responden (26,3\%) dan usia 15 tahun sebanyak 9 responden (12,5\%). 
Tabel 2. Karakteristik sampel penelitian berdasarkan usia

\begin{tabular}{ccc}
\hline $\begin{array}{c}\text { Usia } \\
\text { (tahun) }\end{array}$ & $\mathbf{n}$ & $\begin{array}{c}\text { Persentase } \\
(\mathbf{\%})\end{array}$ \\
\hline 13 & 44 & 61,2 \\
14 & 19 & 26,3 \\
15 & 9 & 12,5 \\
Total & 72 & 100 \\
\hline
\end{tabular}

Pada Tabel 3 distribusi kadar hemoglobin pada anak yang tinggal di sekitar tambang emas Kecamatan Talawaan, dari 72 responden didapatkan 4 responden (5,5\%) mengalami anemia dan 68 responden $(94,5 \%)$ tidak mengalami anemia.

Tabel 3. Distribusi kadar hemoglobin pada anak

\begin{tabular}{ccc}
\hline $\begin{array}{c}\text { Status } \\
\text { hemoglobin }\end{array}$ & Jumlah & $\begin{array}{c}\text { Persentase } \\
\text { (\%) }\end{array}$ \\
\hline Anemia & 4 & 5,5 \\
Non-anemia & 68 & 94,5 \\
Total & 72 & 100 \\
\hline
\end{tabular}

Pada Tabel 4 dapat dilihat dari 72 responden terdapat 31 responden (100\%) berjenis kelamin laki-laki tidak mengalami anemia; tidak terdapat responden $(0 \%)$ yang mengalami anemia.

Tabel 4. Distribusi sampel berdasarkan kadar hemoglobin dan jenis kelamin laki-laki

\begin{tabular}{ccc}
\hline $\begin{array}{c}\text { Status Hb } \\
\text { laki-Laki }\end{array}$ & Jumlah & $\begin{array}{c}\text { Persentase } \\
(\mathbf{\%})\end{array}$ \\
\hline Anemia & 0 & 0 \\
Non Anemia & 31 & 100 \\
Total & 31 & 100 \\
\hline
\end{tabular}

Pada Tabel 5 dapat dilihat dari 72 responden terdapat 37 responden (90,2\%) berjenis kelamin perempuan tidak mengalami anemia dan diperoleh data sebanyak 4 responden $(9,8 \%)$ mengalami anemia.

Pada Tabel 6 didapatkan yang mengalami anemia pada usia 13 tahun terdapat 3 responden, pada usia 14 tahun yang mengalami anemia hanya 1 responden, sedangkan pada usia 15 tahun tidak ada responden yang mengalami anemia. Untuk usia 13 tahun didapatkan juga 41 responden tidak mengalami anemia, usia 14 tahun didapatkan 18 responden tidak mengalami anemia dan untuk usia 15 tahun didapatkan 9 responden tidak mengalami anemia.

Tabel 5. Distribusi sampel berdasarkan kadar hemoglobin dan jenis kelamin perempuan

\begin{tabular}{ccc}
\hline $\begin{array}{c}\text { Status Hb } \\
\text { perempuan }\end{array}$ & Jumlah & $\begin{array}{c}\text { Persentase } \\
(\mathbf{\%})\end{array}$ \\
\hline Anemia & 4 & 9,8 \\
Non-anemia & 37 & 90,2 \\
\hline Total & $\mathbf{4 1}$ & $\mathbf{1 0 0}$ \\
\hline
\end{tabular}

Tabel 6. Distribusi sampel berdasarkan kadar hemoglobin dan usia

\begin{tabular}{ccccc}
\hline $\begin{array}{c}\text { Status } \\
\text { Hemoglobin }\end{array}$ & $\begin{array}{c}\mathbf{1 3} \\
\text { Tahun }\end{array}$ & $\begin{array}{c}\mathbf{1 4} \\
\text { Tahun }\end{array}$ & $\begin{array}{c}\mathbf{1 5} \\
\text { Tahun }\end{array}$ & Total \\
\hline Anemia & 3 & 1 & 0 & 4 \\
Non-Anemia & 41 & 18 & 9 & 68 \\
Total & 44 & 19 & 9 & 72 \\
\hline
\end{tabular}

Dari Tabel 7 distribusi sampel berdasarkan lama tinggal dan usia didapatkan seluruh sampel ( 72 responden) telah lama menetap $<30$ tahun di sekitar tambang emas Kecamatan Talawaan dengan usia 13 tahun diperoleh 44 responden, 14 tahun diperoleh 19 responden sedangkan untuk usia 15 tahun didapatkan 9 responden.

Tabel 7. Distribusi sampel berdasarkan lama tinggal dan usia

\begin{tabular}{ccccc}
\hline $\begin{array}{c}\text { Lama } \\
\text { tinggal }\end{array}$ & $\begin{array}{c}\mathbf{1 3} \\
\text { Tahun }\end{array}$ & $\begin{array}{c}\mathbf{1 4} \\
\text { Tahun }\end{array}$ & $\begin{array}{c}\mathbf{1 5} \\
\text { Tahun }\end{array}$ & Total \\
\hline $\begin{array}{c}<30 \\
\text { Tahun }\end{array}$ & 44 & 19 & 9 & 72 \\
$>30$ & 0 & 0 & 0 & 0 \\
$\begin{array}{c}\text { Tahun } \\
\text { Total }\end{array}$ & 44 & 19 & 9 & 72 \\
\hline
\end{tabular}

\section{BAHASAN}

Dari hasil penelitian yang dilakukan sejak bulan November 2015 - Januari 2016 terhadap siswa SMP yang berada pada rentang umur 13 sampai 15 tahun di Kecamatan Talawaan dengan total diperoleh sampel penelitian sebanyak 72 siswa.

Berdasarkan Tabel 1 dari jumlah sampel penelitian sebanyak 72 responden, di dapatkan 31 responden (43\%) berjenis kelamin laki-laki dan 41 responden (57\%) berjenis kelamin perempuan. Sampel penelitian lebih banyak terpilih yang berjenis kelamin perempuan. 
Pada Tabel 2 dari jumlah sampel penelitian sebanyak 72 responden, didapatkan usia 13 tahun sebanyak 44 responden $(61,2 \%)$, usia 14 tahun sebanyak 19 responden $(26,3)$ dan usia 15 tahun sebanyak 9 responden (12,5\%). Responden berusia 13 tahun menjadi sampel penelitian yang paling banyak terpilih.

Tabel 3 menunjukkan bahwa 68 responden (94,5\%) tidak mengalami anemia, namun, didapatkan 4 responden (5,5\%) mengalami anemia. Anemia didefinisikan sebagai kondisi konsentrasi kadar hemoglobin dalam darah rendah, anemia merupakan masalah kesehatan masyarakat di seluruh dunia. Lebih dari setengah penduduk dunia usia pra sekolah berada di negara-negara yang mengalami anemia sebagai masalah kesehatan masyarakat tingkat berat dengan persentase sebesar 56,3\% dan $57,5 \%{ }^{10}$

Pada Tabel 4 diperoleh 31 responden (100\%) yang berjenis kelamin laki-laki tidak ada yang mengalami anemia, menurut RISKESDAS 2013 anemia cenderung menurun pada kelompok umur anak sekolah, remaja sampai dewasa muda. ${ }^{11}$ Hasil dari RISKESDAS 2007 menurut SK MENKES $5,7 \%$ dan data RISKESDAS 4,2\% menunjukkan bahwa Sulawesi Utara memiliki angka kejadian anemia paling rendah dibandingkan dengan provinsi lain di Indonesia. ${ }^{12}$ Berbeda dengan data pada Tabel 5 berdasarkan hasil pemeriksaan 4 responden $(9,8 \%)$ berjenis kelamin perempuan mengalami anemia.

Remaja laki-laki maupun perempuan dalam masa pertumbuhan membutuhkan energi, protein dan zat-zat gizi lainnya yang lebih baik banyak dibanding dengan kelompok umur lain. Pematangan seksual pada remaja menyebabkan kebutuhan zat besi meningkat. ${ }^{13}$ Di Indonesia yang paling banyak mengalami anemia ialah perempuan sebesar 23,9\% (RISKESDAS 2013). ${ }^{11}$ Kebutuhan zat besi remaja perempuan lebih tinggi dibanding remaja laki-laki, karena dibutuhkan untuk mengganti zat besi yang hilang pada saat menstruasi atau pada masa kehamilan. ${ }^{13} \mathrm{Hal}$ yang sama ditemukan pada penelitian yang di lakukan oleh Baral di Nepal terhadap 308 remaja, $78,3 \%$ diantarannya yang berjenis kelamin perempuan mengalami anemia sedangkan laki-laki hanya 52,3\%. ${ }^{14}$

Tabel 6 memperlihatkan sebagian besar responden tidak mengalami anemia yaitu masing-masing 41 responden tergolong dalam usia 13 tahun, 18 responden pada usia 14 tahun dan 9 responden tergolong dalam usia 15 tahun. Anemia hanya di alami 4 responden dari 72 sampel penelitian, 3 responden tergolong dalam usia 13 tahun dan 1 responden pada usia 14 tahun. Menurut WHO dan pedoman Kemenkes, cut-off points anemia berbeda-beda antar kelompok umur, maupun golongan individu. ${ }^{11}$

Faktor-faktor yang memengaruhi kejadian anemia antara lain merokok, minuman beralkohol, asupan nutrisi, status gizi, social ekonomi, pendidikan, demografi, jenis kelamin dan wilayah. Penelitian oleh Permaesih dan Susilo menemukan bahwa setiap penurunan faktor pendidikan akan membawa risiko anemia sebesar 1,5 kali. Remaja yang tinggal di perkotaan berisiko menjadi anemia sebesar 0,8 kali dan status gizi yang kurang mempunyai kontribusi anemia sebesar 1,5 kali. Penggunaan metode dan alat yang berbeda-beda dapat menjadi faktor lain yang membuat perbedaan terhadap kadar hemoglobin. ${ }^{13}$

Pada penilitian ini, didapatkan 4 responden $(5,5 \%)$ yang mengalami anemia. Menurut Richard et al. (2006) dari hasil penelitian yang telah dilakukan menunjukkan bahwa logam berat yaitu timbal $(\mathrm{Pb})$ dapat menurunkan kadar hemoglobin dalam darah. ${ }^{15}$ Namun, sebagian besar anak-anak yang tinggal di sekitar tambang emas Kecamatan Talawaan tidak mengalami anemia yaitu sebesar 94,5\% (Tabel 3).

Usia sampel penelitian ini hanya berada pada rentang 13 sampai 15 tahun saja. Walaupun sudah sejak kecil tinggal dan menetap di Kecamatan Talawaan hal ini tidak membawa dampak terhadap perubahan kadar hemoglobin sebab dapat dilihat pada Tabel 7 seluruh sampel penelitian yang berjumlah 72 responden telah tinggal dan menetap $<30$ tahun di sekitar tambang emas Kecamatan Talawaan.

Terdapat 44 responden tergolong dalam usia 13 tahun, 19 responden tergolong pada usia 14 tahun dan 9 responden pada usia 15 tahun. Kesehatan akan terganggu jika tubuh terpapar logam berat dalam jangka waktu yang lama (long term exposure). ${ }^{16}$ Menurut Watts (1997) terpapar logam berat bisa menyebabkan keracunan akibat toksin yang masuk dalam tubuh, namun harus terakumulasi dalam tubuh manusia dengan waktu sekitar 20-30 tahun lamannya.

\section{SIMPULAN}

Dari hasil penelitian dan bahasan dapat 
disimpulkan bahwa kadar hemoglobin pada anak relatif normal. Hanya sebagian kecil anak yang berjenis kelamin perempuan yang mengalami anemia.

\section{SARAN}

Diperlukan penelitian lebih lanjut untuk melihat perubahan kadar hemoglobin pada anak yang tinggal di sekitar tambang emas Kecamatan Talawaan.

\section{DAFTAR PUSTAKA}

1. Naldi E. Logam-logam berat pencemar lingkungan dan efek terhadap manusia. Kesehatan Masyarakat. 2010;4;42.

2. Adack J. Dampak pencemaran limbah pabrik tahu terhadap lingkungan hidup. Lex Administratum. 2013;3;78-9.

3. Ferianto, Burhanuddin, Widiastuti $T$. Kadar dan sebaran pencemaran merkuri (Hg) akibat penambangan emas rakyat di lokasi hutan Kerangas Kecamatan Mandor Kabupaten Landak. Fakultas Kehutaan Universitas Tanjungpura; p.183-4. Available from: portalgaruda.org

4. Mulia RM. Kesehatan lingkungan (1st ed). Yogjakarta: Graha Ilmu, 2005; p. 51.

5. Agung LN, Hutamadi R. Paparan merkuri di daerah pertambangan emas rakyat Cisoka, Kabupaten Lebak, Provinsi Banten: Suatu tinjauan geologi medis. Buletin Sumber Daya Geologi. 2012:7;134.

6. Lestari, Edward. Dampak pencemaran logam berat terhadap kualitas air laut dan sumberdaya perikanan. Sains. 2004;8:52-8.

7. Bangun JM. Kandungan logam berat timbal $(\mathrm{Pb})$ dan kadmium (Cd) dalam air, sedimen dan organ tubuh ikan Sokang di Perairan Ancol, Teluk Jakarta Sskripsi]. Bogor: Departemen Manajemen Sumberdaya Perairan Fakultas Perikanan dan Ilmu Kelautan
Institut Pertanian Bogor; 2005.

8. Kurniawan W. Hubungan kadar $\mathrm{Pb}$ dalam darah dengan profil darah pada mekanik kendaraan bermotor di Kota Pontianak [Tesis]. Semarang: Universitas Diponegoro; 2008.

9. Yuniar V. Toksisitas merkuri (Hg) terhadap tingkat kelangsungan hidup, pertumbuhan, gambaran darah dan kerusakan organ pada ikan nila [Skripsi]. Bogor: Departemen Budidaya Perairan Fakultas Perikanan dan Ilmu Kelautan Institut Pertanian Bogor; 2009.

10. Siahaan NR. Faktor-faktor yang berhubungan dengan status anemia pada remaja putri di Wilayah Kota Depok Tahun 2011 [Tesis]. Jakarta: Universitas Indonesia; 2012.

11. Kementerian Kesehatan Republik Indonesia. Riset Kesehatan Dasar Riskesdas 2013. Jakarta: Badan Penelitian dan Pengembangan Kesehatan, 2013.

12. Kementerian Kesehatan Republik Indonesia. Riset Kesehatan Dasar Riskesdas 2007. Jakarta: Badan Penelitian dan Pengembangan Kesehatan, 2007.

13. Permaesih D, Herman S. Faktor-faktor yang mempengaruhi anemia pada remaja. Bul Penel Kesehatan. 2005;33:162-71.

14. Baral KP, Onta SR. Prevalence of anemia amongst adolescents in Nepal. Nepal Med Coll J. 2009;11:179.

15. Dwi LH, Oginawati K. Analisis hematologi dampak paparan timbal pada pekerja pengecetan. Teknik Lingkungan. 2013:1:1.

16. Fikri E, Setiani O, Nurjazuli. Hubungan paparan pestisida dengan kandungan arsen (As) dalam urin dan kejadian anemia. Jurnal Kesehatan Lingkungan Indonesia. 2012;2:29-37. 